\title{
Formulating a Long-Term Employment Strategy for Construction Workforce in Malaysia
}

\author{
Norazlin Mat Salleh¹, Siti Siti Sarah Mat Isa², Syarifah Nur Nazihah Syed Jamalulil ${ }^{3}$, Irma Hanie Ibrahim4, Edelin \\ Hussein $^{5}$ \\ 1,2,3,4,5 Department Of Quantity Surveying, Faculty of Architecture, Planning and Surveying, Universiti Teknologi MARA , Cawangan \\ Perak
}

\begin{abstract}
This paper provides a preliminary idea about the research outline to be conducted by the researcher. Overall idea starts with the unremitting issues regarding skilled construction workforce in Malaysia. Unfortunately, unemployment in Malaysia is becoming increasingly serious. Lack of employment factors there is also a source of unemployment. The main purpose of this research is to investigate the existing strategy to encourage the involvement of local skilled construction workforce (LSCW) onsite. Labour is the main asset in the construction project, even nowadays concerned with the use of advanced technology to reduce costs, labor is still required to drive the technology. Therefore, it is importance to develop a long term strategies to sustain the availability in the industry by implementing questionnaire, interview and ended with validation the framework by professional. The target respondent is Employer (Contractor) and ABM trainee throughout Malaysia. The outcomes dedicate to raise the interest among the youth to choose career as construction workforce, policy maker for revised any policy and employer for hiring LSCW.
\end{abstract}

Construction workforce, local labour, strategy and construction employment

\section{Introduction}

The construction industry accounts for an important part of Malaysian economy. Although relatively small, it is extensively linked with many parts of the economy, in particular with related industries such as those of manufacturing. So construction can be described as some kind of economic engine for Malaysia. Based on the economic report 2014/2015 (Ministry of Finance Malaysia, 2015) Construction Sector contributes $4 \%$ to GDP and employment $9.1 \%$ of the overall workforce in 2015. Even though the statistics presents well enough but in reality construction industry is facing chronic skilled labour shortage on site. It also becomes the greatest challenge facing the Malaysian construction industry.

Moreover, according to S. Mohamed et all (2012), involvement by local workforce is not promising and there is evidence that skilled workers produced by vocational training did not meet industry's standard. Some of them were not entering the construction sector even after undertaking training from construction training institutions. In addition the training institution need to take action and build networking with the industry in order to make sure the entire trainee acquired the jobs and develops their career after graduated.

The Eleventh Malaysian Plan (Ministry of Finance Malaysia, 2015) and Construction Industry Malaysia Plan (CIMP) 2016-2020 (Kementerian Kerjaraya Malaysia, 2014) highlighted this labour issue, to achieve developed nation by 2020 Malaysia requires $60 \%$ of the 1.5 million jobs that will be created will require TVET-related skills. In order to responding to this demand Malaysia will requires to increase its annual intake gradually from 164,000 in 2013 to 225,000 in 2020 . Therefore, the aim of this research to develop a novel framework of 
employment strategy for LSCW to remain sustain in Malaysian Construction Industry (MCI).

\section{Research Background}

The Malaysian Government has invested and funded cripplingly in Technical and Vocational Education Training (TVET) to ensure that Malaysia has enough trained and skilled workers in the future. There are many training institutions developed by the government such as the Akademi Binaan Malaysia (ABM), Institut Kemahiran Mara (IKM), Institut Latihan Industri (ILP) Institut Kemahiran Belia Negara (IKBN) and Vocational College. Based on statistic from the Ministry of Public Work (2014), CIDB targets to train 28, 000 construction personnel in 2014. Since the establishment of the ABM Southern Region in 2001, it has successfully produced 200,000 construction personnel (Judin, 2013). Other than that, the Malaysian government has further decided to upgrade the vocational school to vocational college to show how serious the government is in the field of TVET.

Despite there are many efforts made by the government to produce skilled workforces to cater the future demand of MCI it is remain in shortage especially local skilled workforce. As a result many contractors claimed they have difficulty to employ local labours (S. A. Karib, 2014; Kamal et all, 2012.; F. Salleh et all, 2012; A. Bahaman, 2011; A. R. Ibrahim, 2010; S. Saleh, 2008; A. R. A. Aziz, 2002).

Moreover, in the star online reported by $\mathrm{M}$. Carvalho and R. Rahim, (2016) worsened again the Malaysian government would take 1.5 million workers from Bangladesh to meet the demands of employers, who said that local local workers do not want to work especially in dangerous, difficult and dirty (3D) sectors and too choosy. Previous researcher had identified various reason for trainee of training institution reluctant to join the industry (Shazwani et all, 2012). For short term and quick solution contractor hired legal and illegal foreign labour but this situation will give adverse impact to Malaysia such as to economics, health and social problem because the situation currently is out of control.

In addition, in The Labour Shortage Issues Forum was held at the Caring Society Complex, Penang on the $23^{\text {rd }}$ of September 2010, why Malaysian employers appear to like foreign workers because domestically, the employment situation is inherently and structurally foreign-worker orientated (geared towards low-cost/low-pay, low productivity and redundancies). Reported by Productivity, I., \& Creation, J. (2015) the issues and challenges highlighted in Eleven Malaysia Plan is an inadequate skilled job, heavy reliance on low skilled foreign workers and youth employment in full employment scenario.

Before the trainee entering the construction industry they had negative perception that the industry is 3D (S. Saleh, 2008). The trainees, involved in other job sectors feel that they have a brighter future and more secure with fixed salary, allowance, EPF and promotion. Finally all the efforts and investments made by the government seem is useless and the success rate, if there is any is only a small amount. However none of studies offered a concrete solution to address the issues. Therefore, there is a necessity of MCI to produce and formulate a long term strategies for sustainable LSCW. There needs to be more focus placed on identifying future skill requirements and Occupational Structure (OS) as well as on investment in workforce innovation and up spilling the existing workforce.

\section{Research Objectives}

The objectives of this research are (i) to investigate on existing strategy to encourage the involvement of LSCW in construction industry, (ii) to identify the requirements of the LSCW to sustain in the industry and employer in order to employ them and (iii) to recommend a new framework of employment strategy for LSCW to sustain in Malaysian Construction Industry.

\section{Definition Of Term}

\subsection{Employed}

All persons who, at any time during the reference week worked at least one hour for pay, profit or family gain (as an employer, employee, own-account worker or unpaid family worker). Also considered as employed are persons who did not work during the reference week because of illness, injury, disability, bad weather, leave, labour dispute and social or religious reasons but had a job, farm, enterprise or other family enterprise to return to. Also included are those on temporary lay-off with pay who would definitely be called back to work. Employed persons at work and who had worked less than 30 hours during the reference week because of the nature of their work or due to insufficient work and are able and willing to accept additional hours of work are considered underemployed but are nevertheless included in the "employed" category. 


\subsection{Unemployed}

The unemployed are classified into two that is the actively unemployed and inactively unemployed. The actively unemployed include all persons who did not work during the reference week but were available for work and actively looking for work during the reference week. Inactively unemployed persons include the following categories:

- persons who did not look for work because they believed no work was available or that they were not qualified;

- persons who would have looked for work if they had not been temporarily ill or had it not been for bad weather;

- persons who were waiting for result of job applications; and

- persons who had looked for work prior to the reference week.

(Department Of Statistic Malaysia, 2015)

\subsection{Employment Strategy}

Employment strategy" is defined as "an indicator which represents a desirable future in employment and shows a path towards desired reform." First of all, will start by pointing out a number of employment strategies to demonstrate what employment strategy is like. Employment strategy is made up of a combination of basic principle, strategic objectives in a medium- and long-term perspectives based on the basic ideas, a number of policies required for embodiment of the objectives, and procedures for implementing each of the policies.

The role of employment strategy is to enhance the effectiveness of each of the policies and to more efficiently achieve the strategic objectives by clearly showing the position and directions of the policies to those in administrative jobs as well as to those working for businesses and other workers. Working is vital to economy, and accordingly, employment strategy will cover a variety of issues. What is important is these issues are consistent in the light of objectives. Usual socioeconomic changes may lead to changes at an individual policy level, but basic principle and objectives of the strategy will remain unchanged (Definition, A. 2010).

\section{Literature Review}

According to Department of Education, Science and Training, (2001) skill shortages exist when employers are unable to fill or have considerable difficulty in filling vacancies for an occupation, or specialized skill needs within that occupation, at current levels of remuneration and conditions of employment, and reasonably accessible location. Shortages are typically for specialized and experienced workers, and can coexist with relatively high unemployment overall or in the occupation. An occupation may be in shortage even though not all specializations are in shortage. Occupations may be in shortage in particular geographical areas and not in others. Skill shortages generally involve skills that require a significant period of training and/or experience.

In addition, building a skilled and dynamic workforce to meet the needs of this growth will require government, industry, the community, unions, enterprises and individuals to work together. Throughout the world seriously reviewed and addressed the issues in America action taken are Reform and Reinvigorate the Perkins Act, Encourage Private Funding for Craft Training Programs, Improve the Workforce Investment Act, Make it Easier for Veterans to Get Training and to be Hired, Encourage Partnerships Between Registered Apprenticeship Programs and Community Colleges, Expand Federal Apprenticeship Resources and Collect More Comprehensive Data on All Apprenticeship Programs, Enact Immigration Reform, Offer Community College Career and Technical Programs to High School Students for Free and Make It Easier to Establish Public Schools Focused on Career and Technical Education (The Associated General Contractors of America, 2014). Other than that, in early 2012 Department of Business in Australia's Northern Territory conducted a forum to settle down the issue and successfully produced an Employment strategy (Figure 1).

Same cases happening in Malaysia there are many actions taken relating the issues especially under Construction Industry Development Board (CIDB), according to S. A. Karib, et all (2014) CIDB has established 6 training centres known as the Malaysia Construction Academy or Akademi Binaan Malaysia (ABM). CIDB has also accredited 40 private training centres. All these training centres provide skills training to both existing construction personnel and new workers. Undertake the exercise of accreditation and certification of construction workers. CIDB has amended the Act 520 to broaden its mandate to include the setting of standards; registration of construction personnel; training; accreditation and certification; The Construction Industry Master Plan II (CIMP) 2016 - 2020 which is being developed by CIDB in collaboration with key ministries, government agencies and various organisations representing the construction industry. 
Figure 1: Employment strategy at the glance

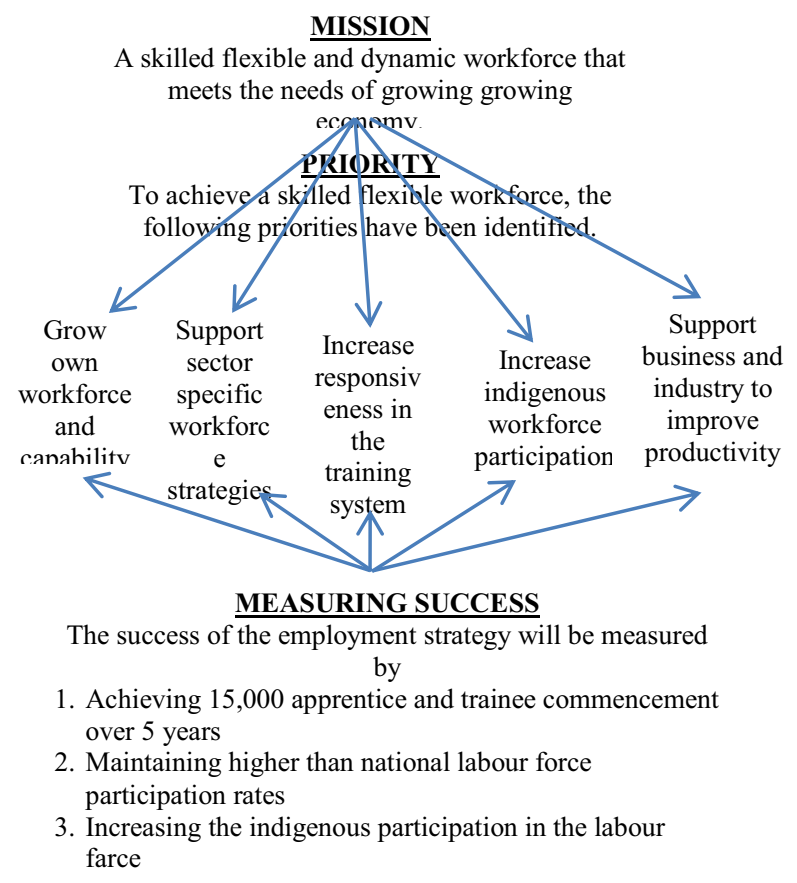

Sources: Northern Territory Employment Strategy 2012-2015

Additionally reported by D. of S. D. (2011), Y.B Datuk Dr. S. Subramaniam, Minister of Human Resource said that, the new skills training programmes would also look at producing more skilled workers for the outsourcing industry, where Malaysia ranks third in the world. The Government had set aside RM 1.0 billion fund to provide loans for school leavers and workers intending to undergo skills training programmes over the next five years. At present, the ministry producers some 18,000 skilled workers via its skills training courses of some 100,000 others graduate from both public and private institutions. The next 10 years will see a greater emphasis on human resource enhancement as availability of skilled and knowledge workers are a major pre-requisite to transform Malaysia from a production-based into a knowledge-based economy.

Malaysia offers investors a young, educated and productive workforce at costs competitive with other countries in Asia. Backed by the government's continued support of human resource development in all sectors, the quality of Malaysia's workforce is one of the best in the region. The Department of Skills Development (DSD) formerly known as the National Vocational Training Council under the Ministry of Human Resources coordinates the setting up of all public and private training institution, evaluates the demand for existing and future skills, identifies future vocational and industrial training needs and will continue to develop standards under the National Occupational Skills Standards (NOSS) (Figure 2). To-date, there are more than 700 certified standards which covers certificate, diploma and advanced diploma qualifications (Malaysia, D. of S. D., 2011).

Figure 2: Development of OA and NOSS and development of policy for training in Malaysia

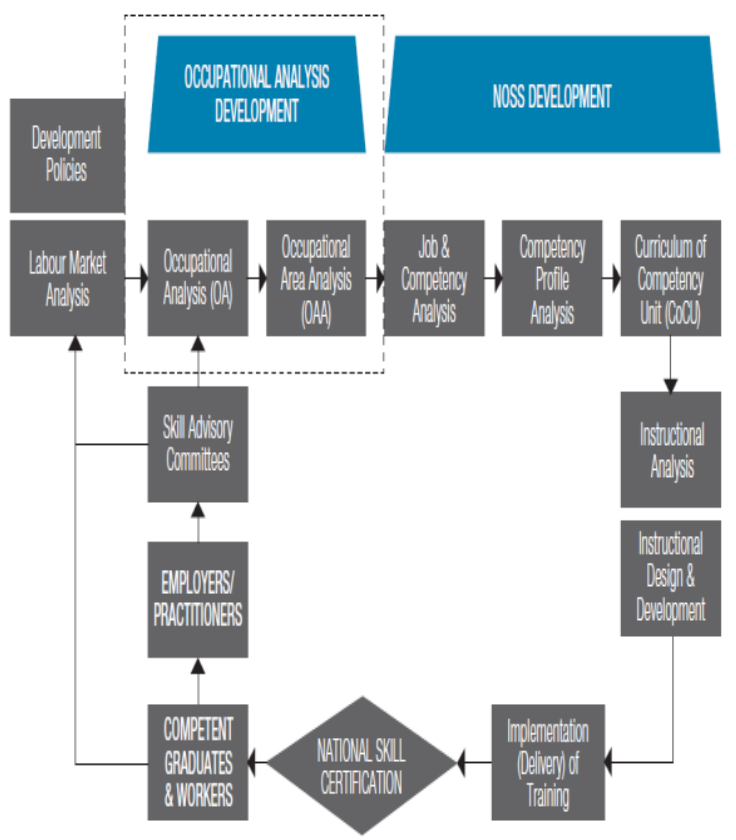

Sources: Department of Skill Development, Ministry of Human Resources, 2013

\section{Research Methodology}

The detail outline of this research will use exploratory research. For example, it is one thing to describe the employment problem in construction site. It is to develop explanations about why the youth is less interest to choose the career in construction, despite the enrollment of trainee to training center is increasingly but the industry is still dependent on foreign nationals on the grounds that employers' awarded local people do not want to work. Therefore to build a framework for long-term employment strategy a research method in the Figure 3 has been identified.

\subsection{Study Population}

Participants for the research will include the ABM trainee throughout Malaysia (Centre, East, Northern and Southern Region). They become a respondent 
because the training they receive is very suitable for work at construction sites such as bricklayer, painter, pavior and etc. Employer as known as Contractor because they will hire the trainee. Professional for conduct Focus Group for validated the framework.

Figure 3: Research Methodology

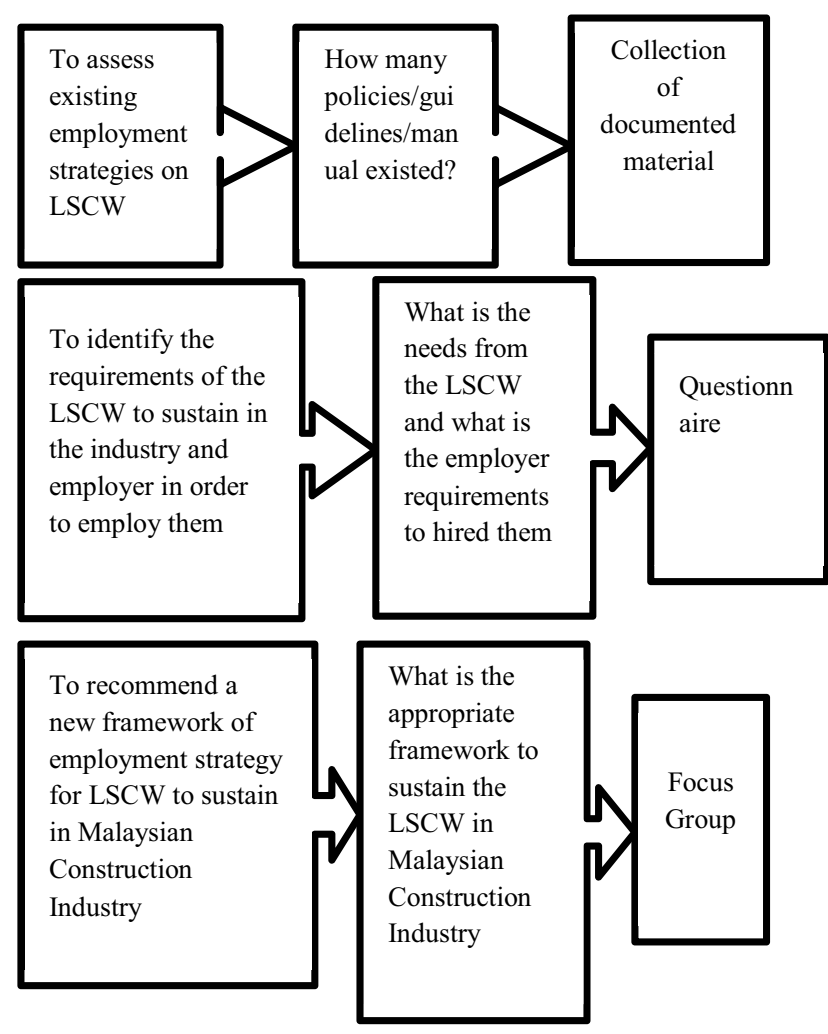

\subsection{Collection of documented material}

Document analysis is a systematic procedure for reviewing or evaluating documents - both printed and electronic material. It is requires that data be examined and interpreted in order to elicit meaning, gain understanding, and develop empirical knowledge. Documents that may be used for systematic evaluation as part of a study take a variety of forms. They include agendas, minutes of meetings; manuals; background papers; books and brochures; journals; newspapers, radio and television program scripts; organisational or institutional reports; survey data; and various public records.

These types of documents are found in libraries, newspaper archives, historical society offices, government bodies and organisational or institutional files. The analytic procedure entails finding, selecting, appraising (making sense of), and synthesizing data contained in documents. Document analysis yields data - excerpts, quotations, or entire passages - that are then organised into major themes, categories, and case examples specifically through content analysis (Bowen A., G., 2009).

\subsection{Questionnaire}

A questionnaire is a research instrument consisting of a series of questions and other prompts for the purpose of gathering information from respondents. The questionnaire will be divided into section consists of demographic and the requirements of trainee and employer. Firstly, respondents (ABM trainee and Contractor) could be asked to complete the questionnaire. Questionnaire will be distributed to respondents by go to the training centre and contractor office or site. In the initial stage the questionnaire will be distributed for the pilot study and for the validity of the questionnaire.

\subsection{Focus Group}

Finally to validate a formulated a long term employment strategy will validate by a professional by conduct a focus group. A focus group is a group of people are asked about their professional idea, comments and improvement toward the strategy. The process for conducting the focus group are, firstly, define a focus group, secondly designing focus group questions, next recruiting and preparing for participants (professional, academicians, employer and policy make representative from CIDB). Subsequently, conducting the focus group and the final stage analyzing the data. The session will recorded by using video as evidence and easy to abstract all the point during analyzing the data.

As a final point, after all the methods have been carried out, the result will be collected and recorded, analyzed and presented in accordance with the required theme. The conclusion and recommendation will be formed from the results of the research.

\section{Conclusion}

Based on the presented preliminary research interest, it can be concluded that, there are many secondary data presented the issues but there are gaps between all the policy makers and the users. Hopefully this research will integrate from all previous data and presented in the meaningful practise. Finally the result from this research will contribute to the development of youth in choosing their career after completed on the training and to move on in the 
employment environment. Furthermore, it may solve a problem too dependent on foreign labour where contributed a lot of negative consequences and at the same time will accelerate Malaysian economics.

\section{References}

1. R. A. Aziz (2002). Skill shortage in the construction sector: A critical survey of existing formal vocational training system. Kajian Malaysia Jld XX, No. 2. Universiti Sains Malaysia.

2. A. R. Ibrahim, M. H. Roy, Z. Ahmed, G. Imtiaz (2010). An investigation of the status of the Malaysian construction industry, Benchmarking: An International Journal, Vol. 17 Iss: 2, pp.294 308.

3. A. Bahaman (2011). The Key Issues in the Malaysian Construction Industry: Public and Private Sector Engagement, Persidangan Pegawai Kanan KKR dan Agensi, Penang, Malaysia

4. B. Vijay Antony Raj \& P. S. Kothai (2014). Study on the Impact of Human Resource Management Practices in Construction Industry. The International Journal of Management Vol 3 Issue 1

5. Bowen A. G. (2009). Document Analysis as a Qualitative Research Method. Quality Research Journal, 9(2), 27-40. http://doi.org/10.3316/qrj090202

6. Department of Education, Science and Training, (2001). Nature and causes of skill shortages Reflections from the Commonwealth National Industry Skills Initiative Working Groups, Department of Employment and Workplace Relations and the National Centre for Vocational Education Research

7. Dom, N. M., Kasim, N., \& Shamsudin, A. (2012). Framework of human resource planning (HRP) influencing factors for local workforce supply in Malaysian construction industry. Journal of Technology Management in China.

8. F. Hassan, Z. Ismail, A. A. Zaini, S. Hassan and M. Maisham, (2011). A Critical Assessment of the Challenges of Developing the Malaysian Construction Workforce through Training, IEEE Colloquium on Humanities, Science and Engineering Research (CHUSER 2011)

9. F. Salleh, A. S. Ali and N. Zakaria (2012). Involment of Foreign Labour in Malaysian construction Industry: Case Study Klang Valley. NCON-PGR 2012

10. G. Ducanes and M. Abella (2008). Labour Shortage Responses in Japan, Korea, Singapore, Hong Kong, and Malaysia: A Review and Evaluation. International Labour Office; ILO
Regional Office for Asia and the Pacific, Asian Regional on Governance of Labour Migration

11. Ilina, O., (2007). Skill shortage. In: Descy, P.;Tessaring M. (eds). Modernisng Vocational eduvation and training. Luxembourg; Europ

12. Kamal, E. M., Haron, S. H., Ulang, N. M., \& Baharum, F. (2012). The critical review on the Malaysian construction industry. J Econ Sustain Dev, 3

13. Kementerian Kerjaraya Malaysia, (2014). CIDB sasar latih 28,000 personnel binaan Malaysia tahun 2014. http://www.kkr.gov.my/

14. Malaysia, D. of S. D. (2011). Occupational Structure the Green Technology Industry, 1-185

15. Ministry of Finance Malaysia (2015). Economic of Prospect Malaysia http://www.treasury.gov.my/pdf/economy/er/141 5/chapter3.pdf

16. M. Carvalho and R. Rahim, (2015). Malaysia and Bangladesh ink deal to recruit 1.5 million workers

http://www.thestar.com.my/news/nation/2016/02 /18/bangladeshi-workers-malaysia-mou/

17. Northern Territory. Department of Business and Employment (2012). Gearing up the workforce: employment strategy. Darwin, NT Department of Business and Employment

18. Organisation for Economic Co-Operation and Development (2004) Developing Highly Skilled Workers: Review of Canada. OECD Publications.

19. Organisation for Economic Co-Operation and Development (2004) Developing Highly Skilled Workers: Review of Finland. OECD Publications.

20. S. Mohamed, S. Fikri, M. Yusof, Zakaria and A. Zaki, (2012). Construction skilled labour shortage the challenges in Malaysian construction sector. OIDA International Journal of Sustainable Development, 4 (5). pp. 100-108. ISSN 1923-6654.

21. S. A. Karib, N. Shaffli. C. S. C. Soh. and N. I. Z. Abidin (2014). Meeting Construction Industry Resources Requirements THE MALAYSIA WAY. Division, Corporate and Business Sector Construction Industry Development Board (CIDB) Malaysia, 20th Asia Construct Conference Hong Kong.

22. S. Saleh (2008). Causes of Poor Participation of Local Workers in Malaysia Construction Industry and Strategies for Improvement. Unpublished Master of Science in Construction Management. Faculty of Civil Engineering University Technology Malaysia.

23. The Associated General Contractors of America (2014). Preparing the Next Generation of Skilled 
Construction Workers: A Workforce

Development Plan for the 21st Century. 